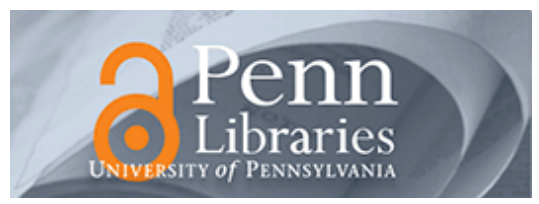

University of Pennsylvania

ScholarlyCommons

GSE Faculty Research

Graduate School of Education

December 1996

\title{
Young African American and Latino Children in High-Poverty Urban Schools: How They Perceive School Climate
}

\author{
Diana Slaughter-Defoe \\ University of Pennsylvania, dianasd@gse.upenn.edu \\ Karen Glinert-Carson \\ Northwestern University
}

Follow this and additional works at: https://repository.upenn.edu/gse_pubs

\section{Recommended Citation}

Slaughter-Defoe, D., \& Glinert-Carson, K. (1996). Young African American and Latino Children in HighPoverty Urban Schools: How They Perceive School Climate. Retrieved from https://repository.upenn.edu/ gse_pubs/66

Permission granted by the Publisher. Reprinted from The Journal of Negro Education, Volume 65, Issue 1, Winter 1996, pages 60-70.

Publisher URL: http://www.jstor.org/journals/00222984.html

NOTE: At the time of publication the author, Diana Slaughter-Defoe was affiliated with Northwestern University. Currently March 2007, she is a faculty member of the Graduate School of Education at the University of Pennsylvania.

This paper is posted at ScholarlyCommons. https://repository.upenn.edu/gse_pubs/66

For more information, please contact repository@pobox.upenn.edu. 


\title{
Young African American and Latino Children in High-Poverty Urban Schools: How They Perceive School Climate
}

\author{
Abstract \\ This article reports findings of a study of third-graders' perceptions of school climate, a key variable of the \\ Comer School Development Program. A self-report survey was individually administered to 1,000 African \\ American and 260 Latino children participating in an evaluation of the Comer process; data were factor- \\ analyzed. African American children viewed teacher-child relations as the most important dimension of \\ school climate. For them, besides acknowledging best efforts, caring teachers listened to children and \\ were available to comfort and help with school and personal problems. Latino children stressed teacher \\ fairness, caring, and praise for effort as well as the importance of moral order. Both groups emphasized \\ following school rules and performing well, values consistent with the Comer process.

\section{Comments} \\ Permission granted by the Publisher. Reprinted from The Journal of Negro Education, Volume 65, Issue 1, \\ Winter 1996, pages 60-70. \\ Publisher URL: http://www.jstor.org/journals/00222984.html \\ NOTE: At the time of publication the author, Diana Slaughter-Defoe was affiliated with Northwestern \\ University. Currently March 2007, she is a faculty member of the Graduate School of Education at the \\ University of Pennsylvania.
}




\title{
Young African American and Latino Children in High-Poverty Urban Schools: How They Perceive School Climate
}

\author{
Diana T. Slaughter-Defoe; Karen Glinert Carlson \\ The Journal of Negro Education, Vol. 65, No. 1. (Winter, 1996), pp. 60-70.
}

Stable URL:

http://links.jstor.org/sici?sici=0022-2984\%28199624\%2965\%3A1\%3C60\%3AYAAALC\%3E2.0.CO\%3B2-8

The Journal of Negro Education is currently published by Journal of Negro Education.

Your use of the JSTOR archive indicates your acceptance of JSTOR's Terms and Conditions of Use, available at http://www.jstor.org/about/terms.html. JSTOR's Terms and Conditions of Use provides, in part, that unless you have obtained prior permission, you may not download an entire issue of a journal or multiple copies of articles, and you may use content in the JSTOR archive only for your personal, non-commercial use.

Please contact the publisher regarding any further use of this work. Publisher contact information may be obtained at http://www.jstor.org/journals/jne.html.

Each copy of any part of a JSTOR transmission must contain the same copyright notice that appears on the screen or printed page of such transmission.

JSTOR is an independent not-for-profit organization dedicated to and preserving a digital archive of scholarly journals. For more information regarding JSTOR, please contact support@jstor.org. 


\title{
Young African American and Latino Children in High-Poverty Urban Schools: How They Perceive School Climate
}

\author{
Diana T. Slaughter-Defoe and Karen Glinert Carlson, \\ Northwestern University*
}

This article reports findings of a study of third-graders' perceptions of school climate, a key variable of the Comer School Development Program. A self-report survey was individually administered to 1,000 African American and 260 Latino children participating in an evaluation of the Comer process; data were factor-analyzed. African American children viewed teacher-child relations as the most important dimension of school climate. For them, besides acknowledging best efforts, caring teachers listened to children and were available to comfort and help with school and personal problems. Latino children stressed teacher fairness, caring, and praise for effort as well as the importance of moral order. Both groups emphasized following school rules and performing well, values consistent with the Comer process.

\section{INTRODUCTION}

Several studies published during the Reagan-Bush years (1980-92) indicate that African American students in $\mathrm{K}-12$ public schools are disproportionately represented in grade retentions, school suspensions, and dropout rates (Bennett \& Harris, 1981; Campbell, 1982; Hess \& Greer, 1987; Hess \& Lauber, 1985; Kaufman, 1991). Similar findings have been reported for Latino children (Chapa \& Valencia, 1993; Reyes \& Valencia, 1993). These studies conclude that prior to leaving school during the adolescent years, these students are frequently poor academic achievers in the elementary grades and experience academic suspensions for related disciplinary problems.

An important trend in the current research focusing on what and how children learn is an increasing appreciation for the overriding importance of developmental factors and continuity. However, this trend was not apparent when Kenneth Clark published Dark

\footnotetext{
*The primary author is also a fellow of the Institute for Policy Research at Northwestern. The secondary author is a former principal in one of the Chicago Comer schools and associate director of Leadership for Quality Education (LQE) in Chicago. The original version of this article was presented as part of a symposium entitled "The Comer Model and Black Children in Chicago Schools: Early Lessons," organized and convened by the primary author for the 16th annual research conference of the Association for Public Policy Analysis and Management, Chicago, IL, October 27-29, 1994. The authors extend special thanks to the following individuals for their contributions to this ongoing research evaluation in general and to this article specifically: Pamela Carter, Thomas Cook, and Meredith Phillips (data analyses and measurement); Patricia Smoot, Avril Weathers, Tamara Perry, and all of our community field testers (supervision and data collection). Also, the continuing cooperation and support of Vivian Loseth and the Youth Guidance facilitators and staff at Chicago's Crane High School are much appreciated. Youth Guidance is the Chicago-based social service agency responsible, under the direction of Loseth, for implementation of the SDP in that city.
} 
Ghetto in 1965. At that time, Clark perceived compensatory programs such as Project Head Start as having mistakenly blamed poor parents and families for their children's educational difficulties. The blame, he believed, fell squarely on school teachers and administrators for not assuming proper responsibility and accountability for the education of low-income and minority children. By 1991, Head Start had endorsed its Transition Project, which focuses on maintaining continuity between the Head Start preschool program and public elementary schools. As a result of this initiative, Head Start staff are trained to work proactively with primary grade teachers to facilitate children's successful entry to and adjustment in the primary grades (Kennedy, 1993).

Increasingly, both elementary and secondary educators acknowledge the important role of family and community in the educative process as active, positive contributors inside and outside the classroom (Lightfoot, 1978; Slaughter-Defoe, 1991; Strickland \& Ascher, 1992). It is far more common today for emphasis to be placed on the need for collaborative partnerships between schools and families at all grade levels in an effort to ameliorate the academic and learning challenges occasioned by deepening, chronic, and persistent poverty (Comer, 1988a, 1988b; McLoyd, 1990; Slaughter, 1988; Wilson, 1989). This dual focus on developmentally appropriate practices in the primary grades and collaborative relationships between children's teachers and families is entirely consistent with the approach to school reform advanced by the School Development Program (SDP) model developed by Dr. James P. Comer $(1980,1998 a)$ at the Yale University Child Development Center. Comer originally piloted his model in public elementary schools serving primarily low-income minority children in New Haven, Connecticut, during the late 1970s. Reflecting on these early efforts, Comer (1980) notes:

The New Haven School System itself developed a number of compensatory education programs. Head
Start and Follow Through programs, designed to overcome learning lags, received considerable support....
We were fully aware that an education program could not correct what was wrong with Dixwell Avenue
or low-income communities through the nation. We also understood that problems in schools in low-
income and affluent communities alike were, in part, due to forces beyond the local schoolhouse. But we
felt that the best way to understand and to begin to cope with problems in and outside of schools, low-income and
affluent alike, was to begin to work in and change at least some of the schools [italics added] ... (pp. 52, 54)

Haynes, Comer, and Hamilton-Lee (1989) conducted a one-year study of the impact of the SDP, particularly its emphasis on parental involvement, on school climate. In their study, 14 schools were randomly assigned to adopt the SDP as a model of school reform; those not adopting the model formed the control group. The sample included 288 children in grades three through five: 176 in the "Comer" schools, and 112 in the control schools. Pretest and posttest data on the children's perceptions of the climate of their classrooms were obtained using Trickett and Moos's (1974) Classroom Environment Scale. Children in the Comer schools showed significant positive change $(p<.001)$, but those in the control schools did not.

Climate is, however, a multidimensional and proximal variable (Witcher, 1993). As Kellam, Branch, Agrawal, and Ensminger (1975) argue, the child's perceived adjustment by classroom teachers is, in many respects, as important as actual adjustment, particularly because teachers' perceptions control instructional inputs as well as the social-emotional climate of the classroom. According to a report issued by the Joint Center for Economic and Policy Studies (1989):

Research has revealed that teachers form negative, inaccurate, and inflexible expectations based on such attributes as the race and perceived social class of their pupils. These expectations result in different treatment of minority and white students and affect the minority students' self-concept, academic motivation, and level of aspiration as they conform, over time, more and more closely to what is expected of them. (pp. 16-17) 
Anson et al. (1991) conducted a careful content analysis of Comer's writings prior to a study of the Comer model in suburban Prince George's County (MD) schools with high percentages of low-income and minority children. They subsequently stressed that a perceptible change in school climate, prior to demonstrable changes in children's academic performance, requires nothing less than "a fundamental change in the structure of governance and in the importance attached to the quality of social interaction within the school" (p. 68). Instead of an atmosphere of conflict and crisis in schools and classrooms, Anson et al. stress that a climate of trust, mutual respect, cooperation, and collaboration between children, their teachers, peers, and parents must be established. When this happens, they assert, the children in these schools will feel safe and supported in their schools and classrooms, attached and involved with school, and bonded to teachers and peers.

The Comer Model provides both the necessary and sufficient context for school change. It enables the ecologically based supports for individual child, parent, and teacher changes to become enduring aspects of these individuals' ongoing interactions and exchanges in the school environment generally and the classroom environment in particular. It predicts changes as a consequence of children's changed perceptions about support for academic learning and their personal capabilities for learning and achievement. Yet it does not merely predict changes in children's achievement performance; these changes occur because caregivers - that is, students' parents and teachers-are perceived by the children as supportive of their earliest efforts to master both social relationships in the school environment as well as the presented instructional tasks. Thus, a proper test of the Comer Model in schools would necessarily include attention to children's social and personal outcomes as a result of a perceived altered school climate.

Despite the centrality of children's perceptions of school and classroom climate to the theoretical aspects of the Comer Model, thus far few studies examining this issue in the primary grades have been undertaken (Comer, Haynes, Joyner, \& Ben-Avie, 1996). The present article reports preliminary data from a study of African American and Latino third-graders' perceptions of school climate, a crucial theoretical component of the Comer Model. ${ }^{1}$ By the conclusion of this research in spring 1997, it is hypothesized that the third graders in the participating Comer schools, in contrast to their peers at non-Comer comparison schools, will report more positive perceptions of school climate. It is also hypothesized that while initially similar, over time the two groups will diverge, with children in Comer schools more positively perceiving school climate than their non-Comer peers. Therefore, the influence of the Comer Model will attenuate negative teacher attitudes toward students, both because students will behave more positively with the introduction of a more hospitable school and classroom climate and because teachers will come to perceive students more favorably.

\section{MeTHOD}

\section{Sample}

Only third-grade African American $(N=1,000)$ and Latino $(N=260)$ children are included in the present analyses. Further, only data from subjects who completed all of the interview protocols on the school climate measure are considered.

${ }^{1}$ The primary author is co-principal investigator of this evaluative study of the SDP, along with Northwestern University colleagues Thomas Cook (principal investigator) and Charles Payne (co-principal investigator). The study is funded by the MacArthur Foundation and the Chicago Community Trust. 


\section{Instruments}

The measure of school climate used in this study was adapted from Habib, Anson, Cook, Clifford, and Antonio's (1993) School Climate Questionnaire (middle-school version), originally designed for use in a study of middle school-aged children in Prince George's County. For children in grades five through eight, alphas ranging from .67 to .90 were obtained by the instrument's developers on items contributing to middle school students' perceptions of school climate in the following areas: (a) predictable and orderly climate, (b) teachers promoting academic performance, (c) student climate (academic/ social), (d) student climate (social), (e) attachment to school, (f) positive relations with adults, (g) school-level affirming climate, (h) home academic environment and style, and (i) home social environment and style. This 90 -item instrument, which is normally groupadministered to children in grades five through eight, was adapted for individual administration to our younger sample.

The resulting 24-item instrument yields information about these younger students' perceptions of relationships with teacher and peers within the school and the classroom setting. Dimensions of climate items assess student valuing of school and its academic goals, students' pride in school, their conventional interpersonal social skills, and peer affiliative climate. Items assessing the dimensions of positive relationships between students and adults in the school focus on students' perceptions of the behaviors teachers use to motivate students, including verbal encouragement of academic performance; how fair adults in the school are; how much they respect students; and how much they care about students. In this measure, children were not queried about home academic and social environment.

\section{Procedures}

School Selection. Schools were phased into the overall study of the Chicago Comer School Development Program. During academic year 1991-92, 4 pilnt schools were introduced; these Phase I schools were not randomly selected and had no matched controls. They were predominantly African American primary schools located in Chicago's westside communities. Like most of the schools selected to implement the SDP model in Chicago in subsequent years, all had ESEA Chapter I eligibility, and over $90 \%$ of their students qualified for free or reduced-price lunches.

In 1992-93, eight more primary schools were introduced into the study. By design, though all eight schools volunteered for the Comer Program, four of these Phase II schools were randomly designated to implement the SDP model and four served as comparison schools. Latino children were significantly represented in two of the eight schools; one of these was a Comer school, while the other was a comparison school. In 1993-94, twelve schools were introduced into the evaluation. Again, though all had volunteered for the Comer program, 6 were randomly designated to receive SDP implementation and 6 became comparison schools. Latino children were significantly represented in 4 of the 12 schools.

Interviewer Selection and Training. During the 1992-93 school year, prospective child interviewers (designated "community field testers") were identified, screened, and trained in a five-week training program. Most of these Phase I field testers were parents of children in one of the four schools; however, parents were not assigned to schools where their own children were enrolled. ${ }^{2}$ All were female and the majority were African American;

${ }^{2}$ In each subsequent year of the study, at least $50 \%$ of these initial trainees returned to work with the project and have served as mentors and role models to new recruits. As a result, the training can now be accomplished in one-and-a-half weeks, and the available pool of field testers will require only minimal training to prepare them for work in subsequent project years. 
however, bilingual Latino and Chinese American field testers were assigned to those schools with higher numbers of Latino and Chinese American children. Each child interviewer was assigned to a minimum of two schools from mid-October through midFebruary, following receipt of parental consent and introduction of the project to participating schools and teachers.

Data Collection. No baseline data were collected in the Phase I schools during the first study year (1991-92). Instead, in the spring of that academic year, an experienced psychometrist individually pilot tested the proposed battery of instruments with children in the primary grades to determine its feasibility for use with the proposed study population. The measure used in this study, the Young Children's Perception of School Climate Questionnaire, was included in the pilot testing.

At Phase II (1992-93), 1 of the 4 pilot Comer schools declined to participate in the child evaluations at any grade level. Community field testers in the primary grades failed to obtain substantial information from this school and from a Phase II Comer and Phase II comparison school. At Phase III (1993-94), data were obtained from 6 Comer and 5 comparison schools, as 1 of the comparisons declined to participate; 4 of the 5 schools not represented were predominantly African American, one was mostly Latino. Thus, data were available on 19 schools, 3 of which were pilot schools, in the first assessment year, and on 11 schools (including 4 pilot schools) in the second assessment year. The schools in phases I and II had been implementing the SDP for one to two years by the time the first third-grade assessment was conducted and from two to three years by the time of the second third-grade assessment. By contrast, the schools that entered into the evaluation process at Phase III were experiencing their first year with the SDP model in 1993-94.

Early in the study, a decision was made to attempt to interview no fewer than 50 children and/or a minimum of $70 \%$ of the children enrolled in grade three. Where there were more than 65 children in grade three at a given school, a table of random numbers was entered, and children were selected for interviews according to the identified numbers up to and including the total number of children in that grade at that school. Otherwise, the entire population of third-graders was sampled. The revised School Climate Questionnaire was individually administered to children in grade three by the field testers.

A total of 299 first-graders and 342 third-graders were individually interviewed in one-hour sessions during Phase II. During Phase III, 935 children were interviewed, all of whom were third-graders.

Independent Variables. Child racial background and school intervention status were the independent variables analyzed in this study. Child racial background was determined by the community field testers in face-to-face interviews with each child. The few subjects with mixed ethnic/racial backgrounds were usually designated "African American." School intervention status refers to the baseline year in which a particular school was phased into the evaluation study. As schools constituted the primary unit of evaluative analysis, primary-grade children were studied cross-sectionally within schools. Resources were not available to follow students longitudinally if they transferred to other schools not participating in this evaluation.

\section{Results}

Before discussing the data shown in Tables I and II, the result of the factor analyses of the data obtained from the Young Children's Perception of School Climate Questionnaire should be presented. In year one, seven factors with eigenvalues greater than one were obtained, but the first factor accounted for $17.2 \%$ of the variance with an eigenvalue of 
TABLE I

Perceptions of School Climate: School Intervention Status and Child Racial Background

\begin{tabular}{|c|c|c|c|c|c|c|c|c|c|c|c|c|}
\hline & \multicolumn{6}{|c|}{ SCHOOL } & \multicolumn{6}{|c|}{ CHILDREN } \\
\hline & \multicolumn{3}{|c|}{ Comer Schools } & \multicolumn{3}{|c|}{ Comparison Schools } & \multicolumn{3}{|c|}{ African American } & \multicolumn{3}{|c|}{ Latino } \\
\hline & Mean & $S D$ & $n$ & Mean & $S D$ & $n$ & Mean & $S D$ & $n$ & Mean & $S D$ & $n$ \\
\hline \multicolumn{13}{|l|}{ YEAR ONE } \\
\hline Phases 1-2 & 2.99 & .332 & 190 & 3.01 & .315 & $112^{\mathrm{a}}$ & 2.99 & .344 & 237 & 3.03 & .245 & 65 \\
\hline Phase 2 & 2.98 & .334 & 89 & 3.01 & .315 & 112 & & & & & & \\
\hline Phase 3 & 3.08 & .309 & 273 & 3.07 & .299 & 221 & 3.07 & .327 & 360 & 3.11 & .231 & 107 \\
\hline Phases 1-3 & 3.04 & .322 & 463 & 3.05 & .306 & 333 & $3.04^{b}$ & .336 & 597 & 3.08 & .239 & 172 \\
\hline \multicolumn{13}{|l|}{ YEAR TWO } \\
\hline Phases 1-2 & $2.95^{\mathrm{c}}$ & .325 & 308 & 3.06 & .354 & $190^{a}$ & 2.98 & .346 & 403 & 3.04 & .306 & 88 \\
\hline Phase 2 & $2.95^{d}$ & .301 & 162 & 3.06 & .334 & 190 & & & & & & \\
\hline
\end{tabular}

Note: Phase 1 schools were four pilot schools nonrandomly selected in 1991-92. Phase 2 schools (original $N=8$ ) were randomly selected in 1992-93; and Phase 3 schools (original $N=12$ ) were randomly selected in 1993-94.

a There were no pilot comparison schools.

${ }^{\mathrm{b}} t(385.25)=1.88, p=.061$, two-tailed

${ }^{c} t(496)=-3.60, p=.000$, two-tailed

${ }^{\mathrm{d}} t(350)=-3.16, p=.003$, two-tailed

4.1247. Seven factors were obtained for year two, with the eigenvalue for the first factor of 4.4079 , accounting for $18.4 \%$ of the variance. The overall climate reliabilities (coefficient alpha) for both years one and two averaged .74. The coefficient alphas for African American children were .75 in year one and .74 in year two; for Latino children, the coefficient alpha was .57 in year one and .72 in year two.

Table I presents data on the sampled African American and Latino children's perceptions of school climate using, first, school intervention status and, second, child racial background as independent variables. These data were obtained from African American third-grade students in three Phase I schools, and from African American and Latino third-grade students in Phase II and III schools. One-way analyses of variance procedures and $t$-tests obtained no significant differences between children in Comer schools and children in comparison schools on the school climate measure in year one. These findings were similar, regardless of when schools were phased into the study. At year two, however, significant differences were obtained on the school climate measure-differences favoring children in comparison schools $(t[496]=-3.60 ; p=.000$, two-tailed). This finding was obtained even when children from the nonrandomly obtained Phase I pilot schools were removed from the sample $(t[350]=-3.16 ; p=.003$, two-tailed). No significant differences were obtained in either years one or two between African American and Latino thirdgraders. In year one, however, there was a trend for Latino children to perceive school climate more favorably than did the African American children $(t[385.25]=1.88 ; p=.061$, two-tailed).

Separate factor analyses were performed on the year one and year two data for the African American and Latino children in the sample (see Table II). Generally, among African American children, six to seven rotated factors were identified (i.e., eigenvalues greater than one); among Latino children, nine. However, eigenvalues for the first factors in each instance are especially high, reaching 4.4159 in year one and 4.3874 in year two 
TABLE II

African American and Latino Third-Grade Children's Perceptions of School Climate

\begin{tabular}{|c|c|c|c|c|}
\hline \multirow[b]{2}{*}{$\begin{array}{l}\text { SCHOOL CLIMATE ITEMS } \\
\text { (Synopsis of item content) }\end{array}$} & \multicolumn{4}{|c|}{ RANK (FACTOR LOADINGS) } \\
\hline & $\begin{array}{l}\text { African American } \\
\text { Year Onne } \\
N=558\end{array}$ & $\begin{array}{l}\text { African American } \\
\text { Year Two } \\
N=353\end{array}$ & $\begin{array}{l}\text { Latino } \\
\text { Year One } \\
N=164\end{array}$ & $\begin{array}{c}\text { Latino } \\
\text { Year Two } \\
N=84\end{array}$ \\
\hline $\begin{array}{l}\text { 1. How many kids in your class } \\
\text { think your school is the best? }\end{array}$ & $11(.481)$ & $12(.430)$ & $12(.406)$ & $15(.422)$ \\
\hline $\begin{array}{l}\text { 2. How many kids in class want to } \\
\text { do well? }\end{array}$ & $19(.379)$ & $6(.501)$ & $18(.176)$ & $1(.650)$ \\
\hline $\begin{array}{l}\text { 3. How many kids in class try hard } \\
\text { to learn? }\end{array}$ & $16(.407)$ & $16(.394)$ & $17(.182)$ & $5(.566)$ \\
\hline 4. How many kids help each other? & $13(.428)$ & $14(.421)$ & $9.5(.422)$ & $14(.461)$ \\
\hline $\begin{array}{l}\text { 5. How many kids share with each } \\
\text { other? }\end{array}$ & & $15(.396)$ & $6(.475)$ & $2(.625)$ \\
\hline 6. How many kids follow rules? & $18(.382)$ & $5(.502)$ & $8(.450)$ & $4(.567)$ \\
\hline $\begin{array}{l}\text { 7. How many friendly older boys } \\
\text { are in your school? }\end{array}$ & & $17(.393)$ & $19(.172)$ & $10(.517)$ \\
\hline $\begin{array}{l}\text { 8. How many friendly older girls are } \\
\text { in your school? }\end{array}$ & $12(.455)$ & $18(.380)$ & $21(.127)$ & $12.5(.490)$ \\
\hline $\begin{array}{l}\text { 9. How friendly are the kids in your } \\
\text { school? }\end{array}$ & $8(.491)$ & $8(.468)$ & $9.5(.422)$ & $7(.549)$ \\
\hline $\begin{array}{l}\text { 10. Are there kids with no friends in } \\
\text { your class; how many? }\end{array}$ & $24(-.029)$ & $23(-.055)$ & $16(.185)$ & $18(.227)$ \\
\hline $\begin{array}{l}\text { 11. Do you worry about being picked } \\
\text { on by kids your age; how much? }\end{array}$ & $22(.064)$ & $22(.030)$ & $24(-.091)$ & $24(-.107)$ \\
\hline $\begin{array}{l}\text { 12. Do you worry about being picked } \\
\text { on by older kids; how much? }\end{array}$ & $23(.032)$ & $24(-.072)$ & $23(-.044)$ & $23(-.100)$ \\
\hline $\begin{array}{l}\text { 13. How much do you like to come } \\
\text { to school? }\end{array}$ & $10(.486)$ & $11(.438)$ & $5(.503)$ & $12.5(.490)$ \\
\hline $\begin{array}{l}\text { 14. How comfortable are you when } \\
\text { meeting new people at your } \\
\text { school? }\end{array}$ & $15(.411)$ & $21(.324)$ & $7(.466)$ & $3(.618)$ \\
\hline 15. How fair is your teacher? & $90)$ & 10 & $1(.581)$ & $17(.372)$ \\
\hline $\begin{array}{l}\text { 16. Does your teacher tell you that } \\
\text { you can do better work? }\end{array}$ & $21(.278)$ & $20(.332)$ & $22(.065)$ & $21(.064)$ \\
\hline $\begin{array}{l}\text { 17. Does your teacher help you if } \\
\text { you ask for help? }\end{array}$ & $7(.499)$ & $4(.511)$ & $15(.328)$ & $22(.033)$ \\
\hline $\begin{array}{l}\text { 18. When you work hard, does your } \\
\text { teacher notice? }\end{array}$ & $3(.527)$ & $2(.585)$ & $3(.517)$ & $8(.538)$ \\
\hline 19. Does your teacher listen to you? & & $1(.6$ & $13(.387)$ & $16(.421)$ \\
\hline $\begin{array}{l}\text { 20. If your teacher calls on you to } \\
\text { answer, how comfortable are you? }\end{array}$ & $5(.515)$ & $9(.455)$ & $4(.505)$ & $6(.560)$ \\
\hline $\begin{array}{l}\text { 21. Do you talk to your teacher } \\
\text { about problems; how much? }\end{array}$ & $6(.513)$ & $13(.429)$ & $11(.420)$ & $20(.163)$ \\
\hline $\begin{array}{l}\text { 22. Does your teacher care about } \\
\text { you; how much? }\end{array}$ & $1(.579)$ & $3(.569)$ & $2(.520)$ & $19(.182)$ \\
\hline $\begin{array}{l}\text { 23. Does your principal care about } \\
\text { you; how much? }\end{array}$ & $20(.315)$ & $19(.367)$ & $20(.141)$ & $11(.509)$ \\
\hline $\begin{array}{l}\text { 24. How nice are the adults in your } \\
\text { school? }\end{array}$ & $14(.413)$ & $7(.495)$ & $14(.362)$ & $9(.518)$ \\
\hline
\end{tabular}

Note: Factor loadings for each item on the first factor obtained in principal component analyses are presented and ranked for each group. 
for African American children; and 3.2938 and 4.8605 in years one and two, respectively, for Latino children. The percentage of variance accounted for by these first factors ranged from a high of $20.3 \%$ to a low of $13.7 \%$. These results are very similar to those obtained from factor analyses of the entire sample population at both years one and two. In addition, the factor loading of each of the 24 items on the first factor for each racial/ethnic group was ranked according to the magnitude of its contribution to that factor, ranging from strongly positive to strongly negative. The rankings within both third-grade groups remained relatively constant between the first and second assessment years.

For both African American and Latino children at year one and year two, whether teachers notice when effort is expended for school work (item 18) had a consistently high (greater than .50) factor loading. However, high factor loadings were also obtained for three of the four racial/ethnic and year groups regarding children's perceptions of whether or not teachers cared about them (item 22), and whether or not students were comfortable addressing a teacher-posed question about schoolwork (item 20). Further, negative peer relations (items 10 through 12) were not stressed in the first factor by any of the four child populations.

Beyond this, the African American and Latino youngsters appeared to differ in terms of the paths emphasized relative to perceptions of school climate. For example, the African American children in the year one sample emphasized interactive teacher-child relations (items 17-22) as the most important dimension of school climate. Apart from noticing when students put forth their best effort, these students indicated that teachers who cared listened to them, were available to comfort them and help them with school work and with problems. By contrast, Latino children stressed teacher fairness, caring, and praise for effort in year one (items 15, 22, 18), but even in grade three, aspects of the larger school environment (e.g., items 13 and 14) were apparently important to them. For these children, the moral order associated with the school as an institution was of great importance.

An emphasis on the quality of teacher-child relations was of continued importance to the year-two cohort of African American third-graders. However, by contrast, among the smaller numbers of Latino students assessed in the second year, the emphasis on peers and the whole school environment (items 3,5, and 14) was found to be especially strong. Nonetheless, in year two but not year one of the evaluation, both African American and Latino third-graders stressed the importance of children following school rules and performing well in class (items 2 and 6).

\section{Discussion}

These preliminary descriptive data suggest that the 24-item measure used to assess young children's perceptions of climate is reasonably reliable and sensitive to both annual changes in overall school climate and to broad variations in the dimensions of the schooling experience that are especially important for diverse cultural groups. Happily, the Comer and comparison school children were found not to differ in year one; but differences were seen in year two and, surprisingly, those differences favored the students in the comparison group. These results, too, are reliable and valid, and are closely linked to issues of implementation of the Comer process in Chicago.

For example, at the beginning of academic year 1993-94, Chicago's public school children were "locked out" of their schools on three separate occasions due to labor and management disputes between the city's board of education, the Chicago Teachers' Union, and the state legislature. As a result, our community field testers were unable to interview children until about a month after the schools finally opened. By that time, members of 
the city's educational communities, including its schoolchildren and their parents, were especially aggravated by the school closings. Parents at the more activist schools openly protested this state of affairs, even bringing their children with them to public discussions and protest marches. Many of the parents from the Comer schools were among these protesters, their heightened involvement fueled in part by the SDP's emphasis on stimulating and activating children's caregivers to question some of their most cherished and long-standing beliefs and values about schooling.

As a result, we attribute the Comer school children's more negative impressions of school climate, compared to those of the children at the comparison schools, to the following conditions:

(1) The Comer school children tended to echo their more actively involved parents' voiced frustration over the failure of school personnel to get on with the business of education. The political turmoil surrounding the school closings and these parents' strong responses to it served to sensitize the children to the reality that something different was occurring for their parents, and that something was not at all pleasant.

(2) The Comer school children's responses were also influenced by the more activist, child-centered focus demanded of and evidenced by Comer school principals and teachers, many of whom were vocal critics of the school closings.

(3) The parents at the comparison schools, who were not similarly empowered to monitor and study their children's schooling experiences, were less prone to convey distress over the school closings or the state of the schools to their children. Consequently, these children were less likely to discern or to voice significant problems with the schools.

Our data indicate that children at both the Comer and comparison schools were getting other messages as well. For instance, between years one and two, both the African American and Latino children in the sample came to highly endorse those items on the school climate measure confirming the importance of performing well academically and following school rules for appropriate student behavior. The statements offered in these two items are clearly consistent with theoretical goals of the Comer model. This finding suggests that concurrence with these two ideals is a necessary proximal transition to incremental improvements in academic performance.

The racial/ethnic group differences in priority of various dimensions of school climate are also deserving of exploration because children's background may strongly influence what they designate as important to a positive school climate. For example, the emphasis that the African American schoolchildren in our sample placed on the importance of the teacher-student affective bond echoes a persistent theme in research on African American education (e.g., Epps, 1992; Lee \& Slaughter-Defoe, 1995). Affective, nurturing teachers are persistently designated as important to the early learning and development of African American children, and frequently African American mothers are identified as the nurturant and teaching role model. Indeed, Comer (1988b) himself has described how his observations of and relationship with his own mother played a crucial role in the development of his model for reforming schools.

By contrast, at least in this study, the Latino children in the sample, the majority of whom were Mexican American, appeared more sensitive to cues in the total school environment, inclusive of peers and the classroom setting, in framing their perspectives on school climate. This possible dependence on social cues was described as early as 1974 by Ramirez and Castaneda, and has recently been discussed and critiqued by several authors who caution against premature stereotyping in this regard (Garcia, 1995; Irvine \& York, 1995; Lomawaima, 1995). Therefore, the findings reported here should be viewed as descriptive and suggestive rather than definitive. 


\section{CONCLUSION}

It is important to search for the main effects of race and culture in any study within a society that is as stratified as that of the United States. Within American society, race, color, and ethnicity are important parameters of social stratification. However, not only are they important to society generally, they are also important to education. As Orfield (1993) recently concludes, since 1968, segregation remains especially high in our nation's large cities, and it reaches serious proportions in mid-sized central cities; further, many African American and Latino students also attend segregated schools in the suburbs of larger metropolitan areas. Thus, racial and cultural segregation is reemerging, and it is doing so in contexts of poverty and substandard educational settings. Orfield argues, and we agree, that not only is there very little research into these newer developments, but little is known about how multiracial and multiethnic educational settings affect the learning and development of participating school children.

The implications of these trends in the social conditions of education for the processes of school reform, inclusive of their implications for prevention models such as the Comer School Development Model and related educational policy developments that are childcentered in focus, are relatively unexplored. Perhaps, as we move in the 1990s toward testing the efficacy of Dr. Comer's idea and the model developed from it in the late 1960s and early 1970s, even if we do not obtain all the answers, we will raise the right questions.

\section{REFERENCES}

Anson, A., Cook, T., Habib, F., Grady, M., Haynes, N., \& Comer, J. (1991, April). The Comer School Development Program: A theoretical analysis. Urban Education, 26(1), 56-82.

Bennett, C., \& Harris, J. J. (1981). A study of the causes of disproportionality in suspensions and expulsions of male and Black students; Part 1: Characteristics of disruptive and non-disruptive students. Washington, DC: U.S. Office of Education.

Campbell, E. L. (1982). School discipline: Policy, procedures, and potential discrimination: A study of disproportionate representation of minority pupils in school suspensions. New Orleans, LA: Mid-South Educational Research Association.

Chapa, J., \& Valencia, R. (1993). Latino population growth, demographic characteristics, and educational stagnation: An examination of recent trends. Hispanic Journal of Behavioral Sciences, 15(2), 165-187.

Clark, K. (1965). Dark ghetto. New York: Harper.

Comer, J. (1980). School power. New York: The Free Press.

Comer, J. (1988a). Educating poor minority children. Scientific American, 259(5), 42-48.

Comer, J. (1988b). Maggie's American dream. New York: New American Library.

Comer, J., Haynes, N., Joyner, E., \& Ben-Avie, M. (1996). Rallying the whole village: The Comer process for reforming education. New York: Teachers College Press.

Epps, E. (1992). Education of African Americans. In M. C. Alkin (Ed.), Encyclopedia of educational research (pp. 49-60). New York: Macmillan.

Garcia, E. (1995). Educating Mexican American students: Past treatment and recent developments in theory, research, policy, and practice. In J. Banks \& C. Banks (Eds.), Handbook of research on multicultural education (pp. 372-387). New York: Macmillan.

Habib, F., Anson, A., Cook, T., Clifford, E., \& Antonio, M. (1993, April). The Comer Middle School Development Program: Formative results of program implementation in Prince George's County, Maryland. Paper presented at the annual meeting of the American Educational Research Association, Atlanta, GA.

Haynes, N., Comer, J., \& Hamilton-Lee, M. (1989). School climate enhancement through parental involvement. Journal of School Psychology, 8(4), 291-299.

Hess, G. A., \& Greer, J. (1987). Bending the twig: The elementary years and the dropout rates in the Chicago Public Schools. Chicago: Spencer Foundation and the Chicago Panel on Public School Policy and Finance. 
Hess, G. A., \& Lauber, D. (1985). Dropouts from the Chicago public schools: Analysis of the classes of 1982, 1983, 1984. Chicago: Lloyd A. Frey Foundation and the Chicago Panel on Public School Policy and Finance.

Irvine, J., \& York, D. (1995). Learning styles and culturally diverse students: A literature review. In J. Banks \& C. Banks (Eds.), Handbook of research on multicultural education (pp. 484-497). New York: Macmillan.

Joint Center for Political and Economic Studies, Committee on Policy and Racial Justice. (1989). Visions of a better way: A Black appraisal of public schooling. Washington, DC: Author.

Kaufman, P. (1991). Dropout rates in the United States: 1990. Washington, DC: National Center for Education Statistics.

Kellam, S., Branch, J., Agrawal, K., \& Ensminger, M. (1975) Mental health and going to school: The Woodlawn program of assessment, early intervention, and evaluation. Chicago: The University of Chicago Press.

Kennedy, E. (1993). The Head Start Transition Project: Head Start goes to elementary school. In E. Zigler \& S. Styfco (Eds.), Head Start and beyond (pp. 97-110). New Haven, CT: Yale University Press.

Lee, C., \& Slaughter-Defoe, D. (1995). Socio-cultural influences in African American education.

In J. Banks \& C. Banks (Eds.), Handbook of research on multicultural education (pp. 348-371). New York: Macmillan. Books.

Lightfoot, S. (1978). Worlds apart: Relationships between families and schools. New York: Basic

Lomawaima, K. (1995). Educating Native Americans. In J. Banks \& C. Banks (Eds.), Handbook of research on multicultural education (pp. 331-347). New York: Macmillan.

McLoyd, V. (1990). The impact of economic hardship on Black families and children: Psychological distress, parenting, and socioemotional development. Child Development, 61, 311-346.

Orfield, G. (1993). The growth of segregation in American schools: Changing patterns of separation and poverty since 1968. Cambridge, MA: Harvard University Press.

Ramirez, M., \& Castaneda, A. (1974). Cultural democracy, bicognitive development, and education. New York: Academic Press.

Reyes, P., \& Valencia, R. (1993). Educational policy and the growing Latino student population: Problems and prospects. Hispanic Journal of Behavioral Sciences, 15(2), 258-283.

Slaughter, D. (Ed.) (1988). Black children and poverty: A developmental perspective (pp. 75-92). San Francisco: Jossey-Bass.

Slaughter-Defoe, D. (1991). Parental educational choice: Some African American dilemmas. Journal of Negro Education, 60(3), 354-360.

Strickland, D., \& Ascher, C. (1992). Low-income African-American children and public schooling. In P. Jackson (Ed.), Handbook of research on curriculum (pp. 609-625). New York: Macmillan. 2(1), 1-12.

Trickett, E., \& Moos, R. (1974). The classroom scale. American Journal of Community Psychology,

Wilson, W. (1989). The truly disadvantaged. Chicago: The University of Chicago Press.

Witcher, A. (1993). Assessing school climate: An important step for enhancing school quality. Bulletin of the National Association of Secondary School Principals, 77(554), 1-5. 